\title{
Personal Protective Equipment and Nurse Self-efficacy due to Coronavirus Disease-19 Pandemic: A Systematic Review
}

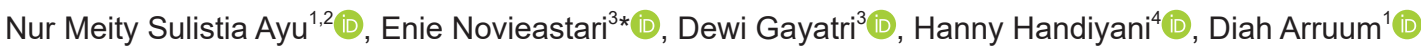 \\ ${ }^{1}$ Doctoral in Nursing Study Program, Faculty of Nursing, Universitas Indonesia, Depok, Indonesia; ${ }^{2}$ Department of Leadership \\ and Nursing Management, Ners Study Program, Stikes Hang Tuah Tanjungpinang, Kepulauan Riau, Indonesia; ${ }^{3}$ Department \\ of Basic Science and Fundamentals Nursing, Faculty of Nursing, Universitas Indonesia, Depok, Indonesia; ${ }^{4}$ Coordinator of \\ Master of Nursing Programs, Faculty of Nursing, Universitas Indonesia, Depok, Indonesia
}

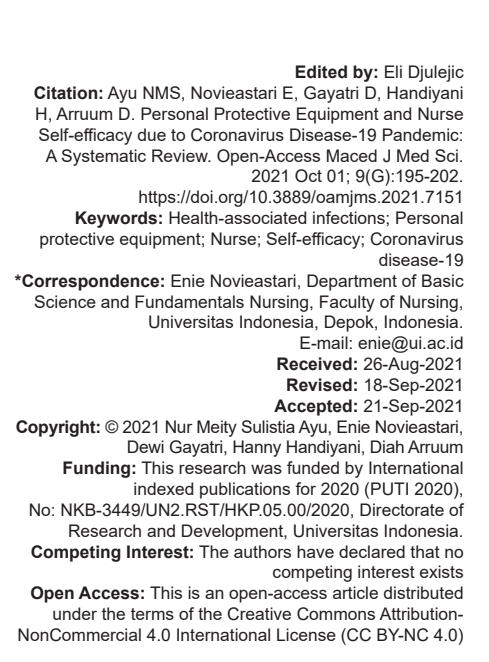

\section{Abstract}

BACKGROUND: High number of nurses who infected and died from contracting coronavirus disease (COVID)-19 put them in a difficult situation during the COVID-19. Personal protective equipment (PPE) is the final line of protection for nurses from the risk of healthcare-associated infections, while self-efficacy plays an important role in surviving stressors during the pandemic.

AIM: This review aims to analyze factors related to the use of PPE and nurse self-efficacy during the COVID-19 pandemic.

METHODS: A systematic and comprehensive search using Preferred Reporting Items for Systematic Reviews and Meta-Analyses with six electronic databases was used. Nine cross-sectional, three cohorts and survey, one case-control, and one surveillance study met the inclusion criteria.

RESULTS: From 104 articles screened, 16 articles were included in this review. High self-protection was the main factor preventing nurses from contracting COVID-19 infection. Lack of PPE and low cautiousness were the primary factor for nurses of contracting COVID-19. Increased stress, anxiety, depressive symptoms, and insomnia were associated with nurse's low self-efficacy.

CONCLUSION: The best protection for nurses from COVID-19 exposure is the availability and consistent use of PPE. Moreover, the consideration for designing staff training programs and psychological support was recommended for building nurses' self-efficacy.

\section{Introduction}

The novel coronavirus disease since 2019 (COVID-19) has become a worldwide threatening pandemic. This disease outbreak begins at the end of 2019 in Wuhan, Hubei Province, China, on March 11, 2020 [1]. The pandemic took a toll of more than 200,000 infected cases around the world in less than 3 months and doubled in less than 2 weeks and soon the WHO has finally declared it as a pandemic [2], [3]. Globally, as of 08:17 am GMT, August 26, 2021, there have been $214,796,388$ confirmed cases of COVID-19, including 4,477,495 deaths reported to the WHO [4]. The increasing infected and death cases have called for the disease to be declared a global emergency [5].

Health care workers (HCWs) including nurses are always on the frontline dealing with pandemic situations. Nurses constitute the largest part of the health care workforce in an epidemic, carrying out most of the tasks related to the infectious disease containment [6]. They are at elevated risk of contracting
COVID-19 compared to others. The shortage of HCWs and an overwhelming number of confirmed cases during the pandemic, nurses overworked and faced numerous stressors, put them more vulnerable to the exposure. The study showed that $10 \%$ of medical staff in America were infected by COVID-19 every week [7]. Nurses to be at the greatest risk of getting exposed to the infection [8], the International Council of Nurses analysis from the National Nursing Associations, the official figures, and the media reports from a limited number of countries, indicated that more than 230,000 HCWs contracted the disease, and more than 1500 nurses died from the virus [9].

The nurse's safety must be ensured to protect them against the virus and prevent its transmission to others. Once a front-liner contracts the disease turn endangers subsequent patients. To prevent exposing others to health and safety risks, nurses follow strict safety and health procedures that entail long working hours, fatigue, and psychological distress. However, these are not the only risk factors present. The cautiousness of being infected or unknowingly infecting 
others was the main source of anxiety in nurses [10]. Moreover, other sources of anxiety include lack of personal protective equipment (PPE), cautiousness of harboring and transmitting the novel coronavirus at work, lack of access to COVID-19 testing, doubt of support from the institution when infected, the uncertainty of being deployed in an unfamiliar ward or unit, and the lack of accurate information regarding the disease [11].

Occupational pressure and psychological distress during the outbreak of infectious diseases experienced by HCWs. The difficult situations faced by nurses are high stressors, working under physical and psychological pressure [12], [13]. When under pressure, nurses with low self-efficacy experience difficulties, stress, and anxiety, which interfere with their job performance. However, there is a lack of systematic appraisal and more critiques observed in the existing studies. Therefore, identifying the factors related to the use of PPE and self-efficacy among frontline nurses, in preventing coronavirus exposure is imperative. Meanwhile, a systematic review is required in summarizing this research regarding the evidence obtained.

\section{Methods}

\section{Study design}

This study was undertaken by the systematic reviews and meta-analyses (PRISMA) guidelines [14].

\section{Search strategy}

This review included the search studies, sought on six electronic databases, namely, ProQuest, EBSCOhost CINAHL, Wiley Online Library, Science Direct, Springer, and Google Scholar. The search terms used were as follows: PPE, COVID-19 OR 2019-ncov, nurse exposure, and self-efficacy, and were conducted in January-August 2020. After the initial search, the titles and abstracts were selected for full-text review (Figure 1).

\section{Inclusion and exclusion criteria}

All studies on the application of PPE and nurses' self-efficacy during the COVID-19 pandemic were included in the study. The results were restricted to only research articles expressed in English.

\section{quality \\ Data extraction and assessment of study}

The articles were independently assessed for the inclusion and exclusion criteria, while data were

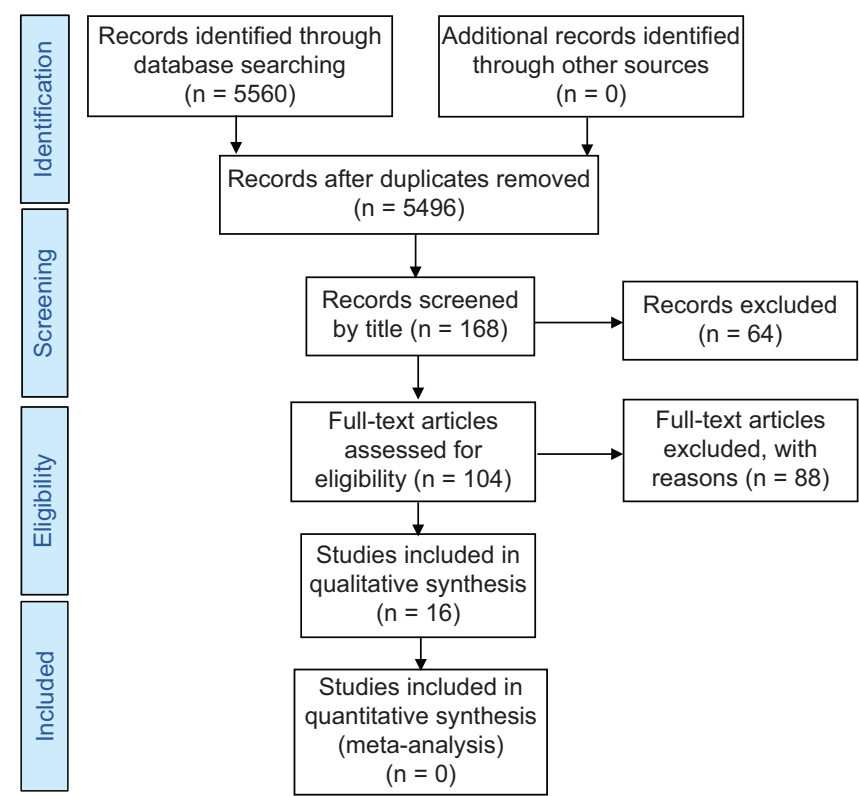

Figure 1: Flow diagram showing selection of articles for review

extracted and resolved for any differences. The following baseline data were extracted from each study, namely, publication year, data collection period, geographical location, and the main findings. The data extracted included the types of PPE recommended, nurses' specific risks and considerations, PPE shortages and rationing, and the factors related to their self-efficacy during the COVID-19 pandemic.

\section{Narrative synthesis}

This was designed based on the heterogeneity and the types that have been published during the emerging COVID-19 pandemic, and a narrative synthesis was performed according to the guidance in the systematic reviews [15]. Then, each article was summarized using bullet points in documenting the key aspects, focusing specifically on the factors related to the use of PPE and nurse self-efficacy during the COVID-19 pandemic.

\section{Results}

\section{Types of studies}

A total of 5560 studies were found in the initial search. After reviewing the duplicates, 5496 studies were screened by their titles and abstracts, leaving 104 full-text reviews for further eligibility tests. Finally, 16 articles were included in this systematic review (Figure 1). Nine cross-sectional, three cohorts and surveys, one case-control, and one surveillance study design met the inclusion criteria (Table 1). The data were collected from all the articles through questionnaires, and no clinical trials studies were found. 
Table 1: PPE and nurses self-efficacy due to the COVID-19 pandemic

\begin{tabular}{|c|c|c|c|c|c|}
\hline $\begin{array}{l}\text { Author/study } \\
\text { year }\end{array}$ & Study site & Study design & Sample size & Instrument & Main findings \\
\hline $\begin{array}{l}\text { Jin et al., } \\
2020[19]\end{array}$ & $\begin{array}{l}\text { Zhongnan } \\
\text { Hospital of Wuhan } \\
\text { University, China }\end{array}$ & Cross sectional & $\begin{array}{l}105 \mathrm{HCWs} \text { of which } 55 \\
\text { were nurses }\end{array}$ & $\begin{array}{l}\text { Validated } \\
\text { questionnaire }\end{array}$ & $\begin{array}{l}\text { Majority thought that they were infected in working environment in } \\
\text { hospital, due to lack of protective equipment, and most staff experienced } \\
\text { psychological stress and emotional changes during their isolation period }\end{array}$ \\
\hline $\begin{array}{l}\text { Wang et al., } \\
2020[20]\end{array}$ & $\begin{array}{l}\text { Zhongnan } \\
\text { Hospital of Wuhan } \\
\text { University, China }\end{array}$ & Cross sectional & $\begin{array}{l}92 \text { medical staffs of } \\
\text { which } 35 \text { were nurses }\end{array}$ & $\begin{array}{l}\text { Self-administered } \\
\text { questionnaire }\end{array}$ & $\begin{array}{l}\text { High self-protection score was the main factor preventing medical staff from } \\
\text { contracting COVID-19 infection. The main factor contributing to COVID-19 } \\
\text { infections among medical staff was touching the cheek, nose, and mouth } \\
\text { while working }\end{array}$ \\
\hline $\begin{array}{l}\text { Papagiannis } \\
\text { et al., } 2020[21]\end{array}$ & $\begin{array}{l}\text { Five public } \\
\text { hospitals, Greek }\end{array}$ & Survey & $\begin{array}{l}461 \mathrm{HCWs} \text { of which } 86 \\
\text { were nurses }\end{array}$ & $\begin{array}{l}\text { A personal interview } \\
\text { questionnaire }\end{array}$ & $\begin{array}{l}\text { There was a high level of knowledge concerning COVID-19 pandemic } \\
\text { among the Greek health care workers, and was significantly associated with } \\
\text { the positive attitudes and practices toward the preventive health measures }\end{array}$ \\
\hline $\begin{array}{l}\text { Chattarjee } \\
\text { et al., } 2020 \text { [22] }\end{array}$ & India & Case control & $\begin{array}{l}751 \text { HCWs of which } 309 \\
\text { were nurses }\end{array}$ & $\begin{array}{l}\text { 20-item brief } \\
\text { questionnaire }\end{array}$ & $\begin{array}{l}\text { The use of PPE was independently associated with the reduction in odds of } \\
\text { getting infected with COVID-19 }\end{array}$ \\
\hline $\begin{array}{l}\text { Liu et al., } \\
2020[17]\end{array}$ & $\begin{array}{l}\text { Four hospitals in } \\
\text { Wuhan, China }\end{array}$ & Cross sectional & $\begin{array}{l}420 \text { health-care } \\
\text { professionals of which } \\
304 \text { were nurses }\end{array}$ & Online questionnaire & $\begin{array}{l}\text { All the participants in the } 420 \text { studies had direct contact with } \\
\text { COVID-19 patients and performed at least one aerosol-generating procedure }\end{array}$ \\
\hline $\begin{array}{l}\text { Delgado et al., } \\
2020 \text { [23] }\end{array}$ & Latin America & Cross sectional & $\begin{array}{l}936 \text { health-care } \\
\text { professionals of which } \\
28 \text { were nurses }\end{array}$ & $\begin{array}{l}12 \text {-item structured } \\
\text { questionnaire }\end{array}$ & $\begin{array}{l}\text { HCWs in Latin America had limited access to essential PPE and support } \\
\text { from health-care authorities during the COVID-19 pandemic. }\end{array}$ \\
\hline $\begin{array}{l}\text { Chu et al., } \\
2020[18]\end{array}$ & $\begin{array}{l}\text { Tongji Hospital, } \\
\text { Wuhan, China }\end{array}$ & $\begin{array}{l}\text { Retrospective } \\
\text { cohort study }\end{array}$ & 54 medical staffs & $\begin{array}{l}\text { Medical staff infection } \\
\text { data }\end{array}$ & $\begin{array}{l}\text { Suggest training for all hospital staffs to prevent infection and preparation of } \\
\text { sufficient protection and disinfection materials }\end{array}$ \\
\hline $\begin{array}{l}\text { Bashirian et al., } \\
2020[24]\end{array}$ & Hamadan, Iran & Cross sectional & $\begin{array}{l}761 \mathrm{HCWs} \text { of which } 231 \\
\text { were nurses. }\end{array}$ & $\begin{array}{l}\text { Self-reported } \\
\text { questionnaire }\end{array}$ & $\begin{array}{l}\text { Threat and coping appraisal were the motivators to conduct COVID-19 } \\
\text { preventive behaviors. Consideration of personnel self-efficacy and their } \\
\text { knowledge regarding the effectiveness of protective behaviors in designing } \\
\text { staff training programs are recommended }\end{array}$ \\
\hline $\begin{array}{l}\text { Hu et al., } \\
2020[13]\end{array}$ & $\begin{array}{l}\text { Two hospitals in } \\
\text { Wuhan, China }\end{array}$ & Cross sectional & $\begin{array}{l}2014 \text { eligible frontline } \\
\text { nurses }\end{array}$ & $\begin{array}{l}\text { Online survey } \\
\text { questioner }\end{array}$ & $\begin{array}{l}\text { Mental health outcomes correlated positively with skin lesion and negatively } \\
\text { with self-efficacy, resilience, social support, and frontline works' willingness }\end{array}$ \\
\hline $\begin{array}{l}\text { Fusco et al., } \\
2020[25]\end{array}$ & $\begin{array}{l}\text { Infectious diseases } \\
\text { hospital in Naples, } \\
\text { Italy }\end{array}$ & Surveillance study & $\begin{array}{l}115 \mathrm{HCWs} \text { of which } 57 \\
\text { were nurses }\end{array}$ & $\begin{array}{l}\text { Serology testing for } \\
\text { COVID-19 records }\end{array}$ & $\begin{array}{l}\text { The overall prevalence of the current or probable previous infection was } \\
3.4 \% \text {. The infection rate among HCWs was reasonably low. Most of the } \\
\text { infected HCWs had been asymptomatic, supporting the need for periodic } \\
\text { screening of HCWs for COVID-19 }\end{array}$ \\
\hline $\begin{array}{l}\text { Felice et al., } \\
2020[26]\end{array}$ & Italy & Survey & $\begin{array}{l}388 \mathrm{HCWs} \text { of which } 101 \\
\text { were nurses }\end{array}$ & $\begin{array}{l}\text { Online survey } \\
\text { questioner }\end{array}$ & $\begin{array}{l}\text { Only } 22 \% \text { of the HCW considered PPE adequate for quality and quantity. } \\
\text { The females and respondents working in high-risk sectors were mostly } \\
\text { affected psychologically and with high workload }\end{array}$ \\
\hline $\begin{array}{l}\text { Xiong and Lin, } \\
2020[27]\end{array}$ & $\begin{array}{l}\text { Fujian Province, } \\
\text { China }\end{array}$ & Cross sectional & 223 nurses & Survey questionnaire & The self-efficacy was negatively correlated with anxiety \\
\hline $\begin{array}{l}\text { Shahrour } \\
\text { and Dardas, } \\
2020[28]\end{array}$ & $\begin{array}{l}\text { Jordanian Hospital, } \\
\text { Jordan }\end{array}$ & $\begin{array}{l}\text { Cross sectional, } \\
\text { descriptive, and } \\
\text { comparative } \\
\text { design }\end{array}$ & 448 nurses & $\begin{array}{l}\text { Web-based survey } \\
\text { questionnaire }\end{array}$ & $\begin{array}{l}\text { Age, ASD, and coping self-efficacy significantly predicted psychological } \\
\text { distress. Furthermore, coping self-efficacy was found to ameliorate the effect } \\
\text { of psychological distress on nurses' traumatic experience }\end{array}$ \\
\hline $\begin{array}{l}\text { Xiao et al., } \\
2020 \text { [29] }\end{array}$ & Wuhan, China & Cross sectional & $\begin{array}{l}180 \text { medical staffs of } \\
\text { which } 98 \text { were nurses }\end{array}$ & Questionnaire & $\begin{array}{l}\text { The anxiety levels were significantly associated with that of stress, which } \\
\text { negatively impacted self-efficacy and sleep quality. Furthermore, anxiety, } \\
\text { stress, and self-efficacy were mediating variables associated with social } \\
\text { support and sleep quality }\end{array}$ \\
\hline $\begin{array}{l}\text { Al-zoubi et al., } \\
2020[16]\end{array}$ & $\begin{array}{l}\text { King Abdullah } \\
\text { University Hospital, } \\
\text { Jordan }\end{array}$ & $\begin{array}{l}\text { Retrospective } \\
\text { single center } \\
\text { cohort study }\end{array}$ & $\begin{array}{l}337 \mathrm{HCWs} \text { of which } 228 \\
\text { were nurses }\end{array}$ & $\begin{array}{l}\text { Swabs using } \\
\text { real-time reverse } \\
\text { transcriptase } \\
\text { RT-PCR records }\end{array}$ & $\begin{array}{l}\text { The prevalence of COVID-19 among HCWs depended on a range of factors, } \\
\text { including the PPE availability, the health-care setting, and access to testing. } \\
\text { The prevalence of COVID-19 among asymptomatic HCWs taking care of } \\
\text { patients was } 0 \%\end{array}$ \\
\hline $\begin{array}{l}\text { Wei et al., } \\
2020 \text { [30] }\end{array}$ & $\begin{array}{l}\text { Wuhan Union } \\
\text { Hospital, China }\end{array}$ & $\begin{array}{l}\text { Prospective cohort } \\
\text { study }\end{array}$ & $\begin{array}{l}14 \mathrm{HCWs} \text { of which } 12 \\
\text { were nurses }\end{array}$ & Medical records & $\begin{array}{l}\text { Among the } 14 \mathrm{HCWs}, 12 \text { were confirmed cases, the other two were } \\
\text { suspected cases. Most of them were either exposed to the index patients or } \\
\text { infected coworkers, without knowing they were COVID-19 patients }\end{array}$ \\
\hline
\end{tabular}

\section{Infections related to PPE use}

From the studies included in this review, high self-protection was the main factor preventing nurses from contracting COVID-19 infection. The types of PPE used were as follows: Gloves, N95 masks with a tight seal around the mouth and nose, the face and eye protection include shields and goggles, and the clothing includes gowns, aprons, head covering, and shoe covers [16], [17]. The protective equipment, such as clothing, N95 masks, and goggles, were given to the first-line medical staff including nurses in fever clinics and wards, while others were given surgical masks. This explained that the lower infection rates among the medical staff were a result of less exposure [18].

The currentreviewshowed that the cautiousness of contracting COVID-19 due to lack of PPE was the primary factor contributing to the high percentage of nurses unable to perform their duties to an acceptable standard. Nurses believed that infection was caused by inadequate provision of protective equipment and also the inadequate protection provided by the available
PPE, wearing only a surgical mask to care for patients with confirmed cases [19]. Meanwhile, 43 (41.8\%) thought that their infection was related to unprotective equipment, such as masks and gloves. Furthermore, there were insufficient reserves of protective equipment in the hospital for a pandemic of such severity [18]. The previous studies showed that most nurses had access to basic PPE, however, many health-care professionals did not have the required equipment recommended by the WHO, particularly disposable and N95 masks [20].

Inappropriate or insufficient infection control measures, such as inconsistent use of PPE and reuse of N95 respirators, were the risk factors of infection in health care. The PPE was not enough at the workplace, however, was readily available in highrisk specialty sectors [21]. HCWs did not have enough PPE, as they often use a nursing mask and not the surgical mask [22]. Initially, when making contact with the patient, their condition was not noticed at that time and the infectiousness of SARS-CoV-2 was also underestimated, therefore, posing greater infection risk. In addition, the use of PPE was independently 
associated with the reduction of being infected with COVID-19 [23]. Furthermore, the infected medical staff was initially asymptomatic, leading to clustered infection in a department [18]. Contrastingly, most of them had been asymptomatic in the preceding 30 days [24].

\section{COVID-19 related to Hospital-Acquired Infections (HAls)}

The unrecognized transmission of pathogens in health-care settings led to the colonization and infection of both patients and medical personnel. Most nurses were infected in the working environment and referred to as HAls [19]. After having close contact with confirmed and suspected patients, they, in turn, mingle with their colleagues at work. Among them had worked more than 7 hours a day in an environment with a high risk of infection [19]. As patients frequently make contact with their caregivers and visitors, they were also at high risk of getting infected. This complicated the infections of medical staff, making it difficult to detect the first infected patient [18]. The exposure to the infected several other colleagues was also another important reason for the infection of COVID-19 in HCWs [22]. The disease was contagious during the incubation period, moreover, much medical staff was not adequately protected and become infected through unwitting contact with the patients [18].

At present, there are three methods of COVID-19 transmission. The top three perceived infection routes were through droplet, contact, and aerosol. They also included direct transmission, whereby droplets released by an infected person while sneezing, coughing, and talking were directly inhaled by an uninfected individual in close contact. Aerosol transmission, whereby droplets and aerosols from an infected person remain airborne for long periods and are mixed with air, subsequently causing the infection through inhalation [25]. The contact transmission occurs from virus droplets deposited on objects' surfaces. This results in contamination of the hands.

The main factor leading to the infection of medical staff was touching the cheek, nose, and mouth while working. In such cases, the infection occurs when contaminated hands touch the mucosa of the mouth, nasal cavity, and eyes. Touching of mouth, nose, and eyes with contaminated hands or gloves by medical staff during work could cause infection. Protective behaviors of HCWs against COVID-19 showed that wearing a glove for all procedures and using a face mask at any time were the least frequent preventive behaviors. The study showed that $7.9 \%$ and $3.7 \%$ of participants never used gloves or a mask during patient care, respectively [26]. Meanwhile, $87 \%$ and $84.6 \%$ always washed their hands frequently with water and soap and avoided mixing with others during the shift [26]. Not touching the cheek, nose, and mouth while working and having high self-protection score were the two superfactors that could reduce the risk of COVID-19 infection in medical staff [25]. This emphasized the need to strengthen the hand, oral, and nasal hygiene practices, especially during epidemics of respiratory infectious diseases. Active personal hygiene measures reduce the risk of COVID-19 transmission, and the vast majority followed special advice from the hospital infectious committee [27].

For nurses, the top three perceived infection causing procedures were sputum suction care, basic nursing, and pharyngeal swab collection (a swab of the throat) [19]. Nurses were responsible for the care of patients in the hospital with severe COVID-19, which included performing aerosol-generating procedures on a routine basis [17]. Around one in $10 \mathrm{HCWs}$ is involved in tracheal intubation for suspected or confirmed patients. However, HCWs performing endotracheal intubation had higher risks of being infected [23].

\section{pandemic \\ Nurses self-efficacy during COVID-19}

Previous reviews found that self-efficacy among frontline nurses was associated with the increased stress, anxiety, depressive symptoms, and insomnia. Self-efficacy was negatively correlated with anxiety $(r=-0.161, p<0.05)$ [28]. The majority of nurses $(64 \%)$ are experiencing acute stress disorder (ASD) due to the COVID-19 pandemic and are at risk for post-traumatic stress disorder (PTSD) predisposition [29]. Furthermore, more than one-third of nurses (41\%) are also suffering significant psychological distress [29]. Age, ASD, and coping self-efficacy significantly predicted psychological distress. More specifically, younger nurses are more prone to experiencing psychological distress than the older. The higher scores on ASD showed more resultant psychological distress while coping self-efficacy was the protective factor [29]. Another study also found that anxiety levels were significantly associated with stress and insomnia, and negatively impacted self-efficacy and sleep quality [30]. In addition, anxiety, stress, and self-efficacy were mediating variables associated with social support and sleep quality [30].

\section{Discussion}

\section{PPE recommendations}

The use of PPE was an important strategy in protecting health-care personnel from contaminating and preventing the spread of pathogens to subsequent patients. Nurses needed to wear procedural masks or respiratory protective equipment (N95), eye protection, gowns, and gloves when giving treatment to COVID-19 patients. A lack and non-availability of 
PPE were the main issues highlighted in this current review. All protective measures were important for workers to be safe when working. A high selfprotection score means that there was the availability of PPE, which was used correctly [25]. Health-care systems should ensure adequate availability of PPE and develop additional strategies in protecting $\mathrm{HCWs}$ from COVID-19 [31].

An assessment of the PPE supply chain and equitable access to it should be a part of the deliberate and informed decision about resource allocation [31]. However, global shortages of masks, respirators, face shields, and gowns caused by surging demand have led to efforts of conserving PPE through extended use or reuse [32], [33]. Studies showed that sufficient availability of PPE with high quality reduced the spread of COVID-19, however, the reuse or its inadequate supply conferred comparably increased risk [31]. The greater risk associated with PPE reuse was related to either self-contamination during repeated application and removal, or breakdown of the clothing materials from extended wear.

Frontline nurses in charge of examining and caring for the infected patients should constantly wear PPE all the time during their shift. Having the right type or size of PPE and wearing it correctly was crucial in preventing COVID-19 infection. Consistent use of PPE was important in reducing HAls [34]. Therefore, it was expected to use PPE appropriately according to the task risk level recommended to be performed by nurses [1]. Studies indicated that appropriate PPE in addition to adhering to standard recommendations had effectively protected nurses from SARS-CoV-2 infection in clinical settings with a high risk of exposure [17]. Contrastingly, most infections occurred through contact and airborne transmission [25].

The fact that some infected HCWs had been asymptomatic for the preceding 30 days supported the need for periodic screening for COVID-19 among them [24]. The prompt exclusion of infected HCWs from the workplace also supported the need for periodic screening. Therefore, it was necessary to improve surveillance of HCWs and to identify the best approach in protecting them, as well as to control and ensure a safe working environment [16]. To protect the HCWs and their families, staff should undergo routine medical checks, including temperature and RT-PCR tests. In addition, HCWs should isolate themselves in the hospital residence and maintain social distancing from family members and other staff.

There was a need to improve the availability of PPE and the HCWs' training. Therefore, the protection of HCWs by authorities should be prioritized through education and training, the readiness of staff, incentives, availability of PPEs, and psychological support [35]. In addition, nurses should be well trained regarding hand hygiene, putting on and taking off PPE, and performing aerosol-generating procedures.
It was also necessary to receive training and education through online mandatory courses according to the updated protocols as issued by the WHO and Centre for Disease Control (CDC) to protect them from hospital-acquired COVID-19 infection. The education should include information on the type of virus, its transmission, disease signs and symptoms, diagnostic criteria, vulnerable patient groups, its treatment, and management protocols. The hospital personnel training should include the type of PPEs, their proper use, cleaning, reuse and disposal, and the nurses' and patient hygiene. In addition, guidelines for all specialties of health-care providers should be issued to protect individuals and prevent the transmission of the infection to nurses and patients. Moreover, standard cleaning and disinfection measures for individuals and premises should be performed religiously to further prevent the spread of the virus and minimize the risk of cross-infection.

However, even with adequate PPE, HCWs caring for COVID-19 patients remained at high risk, highlighting the importance of not only ensuring PPE quality and its availability but also its other aspects of appropriate use, including correct application and removal, and clinical environment [31]. Therefore, the core factors for preventing this infection were timely and proper use of PPE by HCWs [25]. This indicated that effective procedures in protecting staff from infection were very important. Therefore, this implemented a more stringent protocol for nurses as a necessary precaution, which included wearing N95 respirators and surgical masks at the same time.

\section{Nurses self-efficacy improvement}

The current review suggested that nurses were encountering a considerable degree of stress, anxiety, depression, and insomnia due to the pandemic. The fact that they were exposed to the virus daily and were cautious of infecting themselves, families, or patients, therefore, they faced long working hours, high mental workload, stress, and emotional fatigue. Moreover, they were exposed to high doses of pain, emotional suffering, stigma, and physical and psychological violence, due to society's carelessness [1], [36]. There was also fret in the US and the UK regarding the increased levels of stress, anxiety, and exhaustion among HCWs and how all these factors were affecting the efficacy and absenteeism among the personnel [37], [38]. The positive coping strategies and the increased social support were attributed to the decreased psychological distress, increased self-efficacy, improved sleep quality, and decreased levels of anxiety and stress among the nurses [30], [39].

The psychological status of nurses in the public hospital during the COVID-19 outbreak needs more attention. Although, improving their self-efficacy in dealing with emerging infectious diseases was helpful to 
their psychology. Therefore, self-efficacy is commonly defined as having a belief in the ability to succeed and occurs when the individual rises to the challenge of a difficult task and is motivated intrinsically [40]. Mental health outcomes were statistically and negatively correlated with self-efficacy and resilience. The self-psychological adjustment was the core skills for improving nurses' self-efficacy and played a critical role in coping with stress. Mental resilience was the foundation of psychological adjustment, which was an individual's response to stress, and was enhanced through facilitation and training [12]. Taking effective psychological support measures helped frontline nurses psychologically, by relieving and stabilizing fear, anxiety, or sadness caused by the pandemic. These measures also improved resistance and adaptability to crisis and prevented mental disorders.

This condition warrants attention and support from policy-makers. To prevent psychological distress and manage stressful conditions, psychological evaluations and counseling sessions should be available for vulnerable staff. To preserve mental wellbeing, nurses should practice healthy eating, physical activity, a minimum of $6-8$ h of sleep, and communication with family and friends [35]. Providing social and emotional support to HCWs during the pandemic reduced anxiety and stress levels, and increased their self-efficacy [30]. A significant relationship between the knowledge of using PPE with the self-efficacy of COVID-19 management was observed. This means that nurses with the knowledge of using PPE have 2780 times opportunities of acquiring good self-efficacy in managing the condition [41].

\section{Conclusion}

The best protection for nurses from COVID-19 infection is the availability and consistent use of PPE. Furthermore, for health-care professionals to deliver safe care, there is a need for training on the appropriate use of equipment. Until there is a vaccine or proven treatments available, the requirement for nurses to limit their workload and take sensible precautions is imperative in reducing transmission, flattening the curve, protecting themselves and patients, as well as reducing the death tolls.

The insights from this review helped authorities in various countries where the COVID-19 case has not yet been recorded to plan strategically ahead. Moreover, while HCWs carry out their duties to patients, the government is expected to put in place a system for future pandemics that safeguard and preserve the nurse workforce. Therefore, these management strategies should be promptly implemented to enhance safety and optimize resource allocation. However, in the case of rationing PPE, these decisions should be transparent, collaborative, accountable, and adaptable as evidence of the pandemic evolves, rather than disguising the guidelines. As a result, this poses both moral and ethical dilemmas to patient-focused health-care professionals, thereby creating a sense of inadequacy, undervaluation, and workforce stress. The consideration for designing staff training programs and psychological support was recommended for building nurse self-efficacy. The prompt interventions at the national levels are needed to improve mental health by preventing and managing skin lesions, building self-efficacy and resilience, providing sufficient social support, and ensuring that the front-liners work willingly.

\section{Acknowledgment}

The author appreciates all the health workers who have fought hard and are still fighting against COVID-19.

\section{References}

1. Jiang L,BroomeME, Ning C. Theperformanceand professionalism of nurses in the fight against the new outbreak of COVID-19 epidemic is laudable. Int J Nurs Stud. 2020;107:103578. https:// doi.org/10.1016/j.ijnurstu.2020.103578

PMid:32446015

2. Putri SI, Anulus A. Preventive actions to minimizing the coronavirus disease 19 (COVID-19) transmissions among health workers: A systematic review. J Med Sci. 2020;52(3):56205. https://doi.org/10.19106/jmedscisi005203202013

3. Wang C, Horby PW, Hayden FG, Gao GF. A novel coronavirus outbreak of global health concern. Lancet. 2020;395(10223):470-3. https://doi.org/10.1016/ S0140-6736(20)30185-9

PMid:31986257

4. Worldometer. Coronavirus Update (Live): 214,796,388 Cases and 4,477,495 Deaths from COVID-19 Virus Pandemic-Worldometer. Available from: https://www. worldometers.info/coronavirus/\#countries. [Last accessed on 2021 Aug 26].

5. Sohrabi C, Alsafi Z, O'Neill N, Khan M, Kerwan A, Al-Jabir A et al. World Health Organization declares global emergency: A review of the 2019 novel coronavirus (COVID-19). Int J Surg. 2020;76:71-6. https://doi.org/10.1016/j.ijsu.2020.02.034 PMid:32112977

6. Said NB, Chiang VC. The knowledge, skill competencies, and psychological preparedness of nurses for disasters: A systematic review. Int Emerg Nurs. 2020;48:100806. https:// doi.org/10.1016/j.ienj.2019.100806

7. Baker MG, Peckham TK, Seixas NS. Estimating the burden of United States workers exposed to infection or disease: A key factor in containing risk of COVID-19 infection. PLoS One. 2020;15(4):e0232452. https://doi.org/10.1371/journal. pone. 0232452 
PMid:32343747

8. $\mathrm{Ng} \mathrm{K}$, Poon BH, Kiat Puar TH, Shan Quah JL, Loh WJ, Wong YJ, et al. COVID-19 and the risk to health care workers: A case report. Ann Intern Med. 2020;172(11):766-7. https://doi. org/10.7326/L20-0175

PMid:32176257

9. ICN. International Council of Nurses Confirms 1,500 Nurses Have Died From COVID-19 in 44 Countries. Targeted News Service; 2020. Available from: https://www.search.proquest. $\mathrm{com} / \quad$ newspapers/international-council-nurses-confirms-1500-have/ docview/2455532236/se-2?accountid=17242 [Last accessed on 2020 Oct 29].

10. Mo Y, Deng L, Zhang L, Lang Q, Liao C, Wang N, et al. Work stress among Chinese nurses to support Wuhan in fighting against COVID-19 epidemic. J Nurs Manage. 2020;28(5):1002-9. https://doi.org/10.1111/jonm.13014 PMid:32255222

11. Shanafelt T, Ripp J, Trockel M. Understanding and addressing sources of anxiety among health care professionals during the COVID-19 pandemic. JAMA. 2020;323(21):2133-4. https://doi. org/10.1001/jama.2020.5893

PMid:32259193

12. Chen H, Sun L, Du Z, Zhao L, Wang L. A cross-sectional study of mental health status and self-psychological adjustment in nurses who supported Wuhan for fighting against the COVID-19. J Clin Nurs. 2020;29(21-22):4161-70. https://doi.org/10.1111/ jocn. 15444

PMid:32757428

13. Hu D, Kong Y, Li W, Han Q, Zhang X, Zhu LX, et al. Frontline nurses' burnout, anxiety, depression, and fear statuses and their associated factors during the COVID-19 outbreak in Wuhan, China: A large-scale cross-sectional study. EClinicalMedicine. 2020;24:100424. https://doi.org/10.1016/j.eclinm.2020.100424 PMid:32766539

14. Liberati A, Altman DG, Tetzlaff J, Mulrow C, Gøtzsche PC, loannidis JP, et al. The PRISMA statement for reporting systematic reviews and meta-analyses of studies that evaluate healthcare interventions: Explanation and elaboration. BMJ. 2009;339:b2700. https://doi.org/10.1136/bmj.b2700

15. Campbell M, McKenzie JE, Sowden A, Katikireddi SV, Brennan SE, Ellis $\mathrm{S}$, et al. Synthesis without meta-analysis (SWiM) in systematic reviews: Reporting guideline. BMJ. 2020;368:I6890. https://doi.org/10.1136/bmj.l6890

16. Al-zoubi NA, Obeidat BR, Al-Ghazo MA, Hayajneh WA, Alomari AH, Mazahreh TS, et al. Prevalence of positive COVID-19 among asymptomatic health care workers who care patients infected with the novel coronavirus: A retrospective study. Ann Med Surg. 2020;57:14-6. https://doi.org/10.1016/j. amsu.2020.06.038

PMid:32690991

17. Liu M, Cheng SZ, Xu KW, Yang Y, Zhu QT, Zhang H, et al. Use of personal protective equipment against coronavirus disease 2019 by healthcare professionals in Wuhan, China: Cross sectional study. BMJ. 2020;369:m2195. https://doi.org/10.1136/ bmj.m2195

18. Chu J, Yang $\mathrm{N}$, Wei $\mathrm{Y}$, Yue $\mathrm{H}$, Zhang $\mathrm{F}$, Zhao J, et al. Clinical characteristics of 54 medical staff with COVID-19: A retrospective study in a single center in Wuhan, China. J Med Virol. 2020;92(7):807-13. https://doi.org/10.1002/jmv.25793 PMid:32222986

19. Jin $Y H$, Huang $Q$, Wang $Y Y$, Zeng $X T$, Luo LS, Pan ZY, et al. Perceived infection transmission routes, infection control practices, psychosocial changes, and management of COVID-19 infected healthcare workers in a tertiary acute care hospital in Wuhan: A cross-sectional survey. Mil Med Res. 2020;7(1):24. https://doi.org/10.1186/s40779-020-00254-8
PMid:32393381

20. Delgado D, Wyss Quintana F, Perez G, Sosa Liprandi A, Ponte-Negretti C, Mendoza I, et al. Personal safety during the COVID-19 pandemic: Realities and perspectives of healthcare workers in Latin America. Int J Environ Res Public Health. 2020;17(8):2798. https://doi.org/10.3390/ijerph17082798 PMid:32325718

21. Felice C, Di Tanna GL, Zanus G, Grossi U. Impact of COVID-19 outbreak on healthcare workers in Italy: Results from a national E-survey. J Community Health. 2020;45(4):675-83. https://doi. org/10.1007/s10900-020-00845-5 PMid:32440724

22. Wei XS, Wang XR, Zhang JC, Yang WB, Ma WL, Yang BH, et al. A cluster of health care workers with COVID-19 pneumonia caused by SARS-CoV-2. J Microbiol Immunol Infect. 2021;54(1):54-60. https://doi.org/10.1016/j.jmii.2020.04.013 PMid:32359943

23. Chatterjee $P$, Anand T, Singh $K$, Rasaily R, Singh R, Das S, et al. Healthcare workers and SARS-CoV-2 infection in India: A casecontrol investigation in the time of COVID-19. Indian J Med Res. 2020;151(5):459-67. https://doi.org/10.4103/ijmr.ijmr_2234_20 PMid:32611916

24. Fusco FM, Pisaturo M, lodice $V$, Bellopede $R$, Tambaro O, Parrella G, et al. COVID-19 among healthcare workers in a specialist infectious diseases setting in Naples, Southern Italy: Results of a cross-sectional surveillance study. J Hosp Infect. 2020;105(4):596-600. https://doi.org/10.1016/j.jhin.2020.06.021 PMid:32565367

25. Wang $Y$, Wu W, Cheng $Z$, Tan $X$, Yang $Z$, Zeng $X$, et al. Super-factors associated with transmission of occupational COVID-19 infection among healthcare staff in Wuhan, China. J Hosp Infect. 2020;106(1):25-34. https://doi.org/10.1016/j. jhin.2020.06.023

PMid:32574702

26. Bashirian S, Jenabi E, Khazaei S, Barati M, Karimi-ShahanjariniA, Zareian S, et al. Factors associated with preventive behaviours of COVID-19 among hospital staff in Iran in 2020: An application of the protection motivation theory. J Hosp Infect. 2020;105(3):430-3. https://doi.org/10.1016/j.jhin.2020.04.035 PMid:32360337

27. Papagiannis D, Malli F, Raptis DG, Papathanasiou IV, Fradelos EC, Daniil Z, et al. Assessment of knowledge, attitudes, and practices towards new coronavirus (SARS-CoV-2) of health care professionals in greece before the outbreak period. Int J Environ Res Public Health. 2020;17(14):4925. https://doi. org/10.3390/ijerph17144925 PMid:32650614

28. Xiong $\mathrm{H}, \mathrm{Yi}$ S, Lin Y. The psychological status and self-efficacy of nurses during COVID-19 outbreak: A cross-sectional survey. Inquiry.2020;57:1-6. https://doi.org/10.1177/0046958020957114 PMid:32900271

29. Shahrour G, Dardas LA. Acute stress disorder, coping self-efficacy and subsequent psychological distress among nurses amid COVID-19. J Nurs Manage. 2020;28(7):1686-95. https://doi.org/10.1177/0046958020957114 PMid:32767827

30. Xiao H, Zhang Y, Kong D, Li S, Yang N. The effects of socia support on sleep quality of medical staff treating patients with coronavirus disease 2019 (COVID-19) in January and February 2020 in China. Med Sci Monit. 2020;26:e923549. https://doi. org $/ 10.12659 / \mathrm{msm} .923549$

PMid:32132521

31. Nguyen LH, Drew DA, Graham MS, Joshi AD, Guo CG, Ma W, et al. Risk of COVID-19 among front-line health-care workers and the general community: A prospective cohort study. Lancet 
Public Health. 2020;5(9):e475-83.

32. Fischer RJ, Morris $\mathrm{DH}$, van Doremalen $\mathrm{N}$, Sarchette $\mathrm{S}$ Matson MJ, Bushmaker T, et al. Assessment of N95 respirator decontamination and re-use for SARS-CoV-2. MedRxiv. 2020;26(9):2253-5. https://doi.org/10.31219/osf.io/phcsb PMid:32511432

33. Livingston $E$, Desai A, Berkwits M. Sourcing personal protective equipment during the COVID-19 pandemic. JAMA. 2020;323(19):1912-4. https://doi.org/10.1001/jama.2020.5317 PMid:32221579

34. Verbeek J, Rajamaki B, ljaz S, Sauni R, Toomey E, Blackwood B, et al. Personal protective equipment for preventing highly infectious diseases due to exposure to contaminated body fluids in healthcare staff. Cochrane Database Syst Rev. 2020;4:CD011621. cd011621.pub5 PMid:27093058

35. Ali S, Noreen S, Farooq I, Bugshan A, Vohra F. Risk assessment of healthcare workers at the frontline against COVID-19. Pak J Med Sci Quart. 2020;36(S4):S99-103. https://doi.org/10.12669/ pjms.36.covid19-s4.2790

PMid:32582323

36. Huang L, Xu F, Liu H. Emotional responses and coping strategies of nurses and nursing college students during COVID-19 outbreak. MedRxiv. 2020;15(8):e0237303. https:// doi.org/10.1101/2020.03.05.20031898

37. Ehrlich $\mathrm{H}$, McKenney M, Elkbuli A. Strategic planning and recommendations for healthcare workers during the COVID-19 pandemic. Am J Emerg Med. 2020;38(7):1446-7. https://doi. org/10.1016/j.ajem.2020.03.057

PMid:32273142

38. Walton M, Murray E, Christian MD. Mental health care for medical staff and affiliated healthcare workers during the COVID-19 pandemic. Eur Heart J Acute Cardiovasc Care. 2020;9(3):241-7. https://doi.org/10.1177/2048872620922795 PMid:32342698

39. Yu H, Li M, Li Z, Xiang W, Yuan Y, Liu Y, et al. Coping style, social support and psychological distress in the general Chinese population in the early stages of the COVID-19 epidemic. BMC Psychiatry. 2020;20(1):426. https://doi.org/10.21203/ rs.3.rs-20397/v2

40. Boswell SS. "I deserve success": Academic entitlement attitudes and their relationships with course self-efficacy, social networking, and demographic variables. Soc Psychol Educ Int J. 2012;15(3):353-65. https://doi.org/10.1007/ s11218-012-9184-4

41. Simak V, Kristamuliana $\mathrm{K}$. The relationship between knowledge of the use of personal protective equipment and the self efficacy of Puskesmas nurses against Covid-19 management. IJNMS. 2020;4(2):304. https://doi.org/10.29082/ijnms/2020/vol4/ iss $2 / 304$ 